with chronic stable asthma responds appropriately to hypoxia. We suggest that in the presence of chronic hypoxia the value of $\mathrm{PaCO}_{2}$ taken as "normal" should be that predicted by the relation of $\mathrm{PaCO}_{2}$ to $\mathrm{PaO}_{2}$ shown in figure 1-that is, a $\mathrm{PaCO}_{2}$ of $5.3 \mathrm{kPa}(40 \mathrm{~mm} \mathrm{Hg})$ would be normal if $\mathrm{PaO}_{2}$ were $13.3 \mathrm{kPa}$ $(100 \mathrm{~mm} \mathrm{Hg}$ ) but abnormally high and indicating hypoventilation if $\mathrm{PaO}_{2}$ were low. The "normal" $\mathrm{PaCO}_{2}$ would be $3.7 \mathrm{kPa}$ $(28 \mathrm{~mm} \mathrm{Hg})$ at a $\mathrm{PaO}_{2}$ of $6.7 \mathrm{kPa}(50 \mathrm{~mm} \mathrm{Hg})$.

We considered that patients who are severely ill from asthma might not show the acclimatisation response to hypoxia because respiratory control is abnormal or because of severe mechanical impairment to ventilation. Rees $e t a^{3}$ reported arterial blood-gas values for patients with status asthmaticus. We examined the relation of $\mathrm{PaCO}_{2}$ to $\mathrm{PaO}_{2}$ by plotting the values obtained in their patients on the day of admission (fig 2). In all patients $\mathrm{PaCO}_{2}$ was above the value predicted from our patients with chronic stable asthma. Many of the patients of Rees et al would already be regarded as severely ill on the basis of their arterial blood-gas and $\mathrm{pH}$ values. There remains a group with a $\mathrm{PaCO}_{2}$ of about $5.3 \mathrm{kPa}$ ( $40 \mathrm{~mm} \mathrm{Hg}$ ), however, in whom we suggest ventilatory control was impaired. These patients had therefore failed to adjust their ventilation normally, even though most of them had probably been severely ill and hypoxic for several days. ${ }^{6-8}$

In conclusion, we suggest that the relation between $\mathrm{PaCO}_{2}$ and $\mathrm{PaO}_{2}$ in patients with chronic stable asthma $\left(\mathrm{PaCO}_{2}\right.$ predicted $=$ $0.23 \mathrm{PaO}_{2}+2.2 \mathrm{kPa}$ (or $16.6 \mathrm{~mm} \mathrm{Hg}$ )) be adopted as a criterion for assessing adequacy of ventilatory control. Values of $\mathrm{PaCO}_{2}$ above this predicted normal indicate impaired ventilatory control and may give early warning of impending decompensa- tion in patients severely ill from asthma even when the arterial $\mathrm{pH}$ is normal.

We thank Professor T J H Clark for his help and encouragement with this study.

JGP was supported by the Sir Philip Oppenheimer Research Fellowship, department of medicine, Guy's Hospital.

GMC and CBW are in receipt of a MRC research grant.

Requests for reprints should be sent to Dr G M Cochrane, Department of Medicine, Respiratory Laboratory, 18th Floor, Guy's Tower, Guy's Hospital, London SE1 9RT.

\section{References}

1 Wolff CB. Normal respiration in chronic hypoxia. $\mathcal{F}$ Physiol 1980;308: 118-9P.

2 Rebuck AS, Read J. Assessment and management of severe asthma. $A m \mathcal{F}$ Med $1971 ; 51: 788-98$

${ }^{3}$ Rees HA, Millar JS, Donald KW. A study of the clinical course and arterial blood gas tension of patients in status asthmaticus. $Q \mathcal{F}$ Med $1968 ; 37: 541-61$.

${ }^{4}$ McFadden ER, Kiser R, DeGroot WJ. Acute bronchial asthma. $N$ Engl f Med 1973;288:221-5.

${ }^{5}$ Cochrane GM, Benatar SR, Davis J, Collins JV, Clark TJH. Correlation between tests of small airway function. Thorax 1974;29:172-8.

${ }^{6}$ MacDonald JB, MacDonald ET, Seaton A, Williams DA. Asthma deaths in Cardiff 1963-74: 53 deaths in hospital. Br Med $\mathcal{F}$ 1976;ii:721-3.

7 Bellamy D, Collins JV. "Acute" asthma in adults. Thorax 1979;34:36-9.

8 Ormerod LP, Stableforth DE. Asthma mortality in Birmingham 1975-77: 53 deaths. Br Med f 1980;280:687-90.

\title{
Changes in glycosylated haemoglobin after poor control in insulin-dependent diabetics
}

\author{
ANDREW P BROOKS, ISOBEL M NAIRN, JOYCE D BAIRD
}

\section{Summary and conclusions}

Glycosylated haemoglobin $\left(\mathrm{Hb}_{1}\right)$ was measured in seven insulin-dependent diabetic patients before, during, and after a seven-day period of monitored poor control. There was considerable individual variation in the pattern and degree of change in $\mathbf{H b A}_{1}$ concentration induced by poor control and the time when it occurred. Greater increases in $\mathbf{H b A}_{1}$ were seen during the period of metabolic derangement than in the subsequent two months.

More information is required before $\mathrm{HbA}_{1}$ estimations are widely used clinically to monitor control in individual diabetics.

\section{Introduction}

Concentrations of glycosylated haemoglobin $\left(\mathrm{HbA}_{1}\right)$ are raised in diabetic patients and, since the glucose linkage is considered

\footnotetext{
Metabolic Unit, University of Edinburgh, Department of Medicine, Western General Hospital, Edinburgh

ANDREW $\mathbf{P}$ BROOKS, MRCP, MD, lecturer in medicine (now senior registrar, Department of Medicine, Ipswich Hospital, Ipswich) ISOBEL M NAIRN, BSC, senior biochemist

JOYCE D BAIRD, MA, FRCP, senior lecturer in medicine
}

to be relatively stable, are thought to reflect the mean blood glucose concentration during the preceding one to two months. Hence $\mathrm{HbA}_{1}$ estimations are being used as a means of monitoring the degree of overall control of blood glucose achieved in individual diabetics. There are, however, many problems associated with measuring $\mathrm{HbA}_{1}$ and neither the time relation between changes in blood glucose and $\mathrm{HbA}_{1}$ concentrations nor the stability of $\mathrm{HbA}_{1}$ nor its sensitivity in detecting poor control has been clearly defined.

We compared two common methods of estimating $\mathrm{HbA}_{1}$ and examined the change in concentration of $\mathrm{HbA}_{1}$ resulting from a period of poor control deliberately induced in longstanding, insulin-treated diabetic patients maintained under strictly monitored, metabolic conditions.

\section{Patients and methods}

One male and six female diabetic patients being treated with insulin were studied (table I). All were fully ambulant, none was obese, and none had retinopathy, neuropathy, or nephropathy. All gave informed consent to the investigation.

The study covered 13 weeks and was divided into three periods. In the initial three-week assessment period patients were at home following their usual diet and insulin regimen and undertaking normal activity. They were visited each week on the morning after completing a 24-hour urine collection for measuring urinary glucose excretion, and fasting blood was taken for estimating whole blood true glucose, serum lipid, and $\mathrm{HbA}_{1}$ concentrations. 
TABLE I-Clinical details of patients studied

\begin{tabular}{|c|c|c|c|c|c|c|c|c|}
\hline \multirow{2}{*}{ Case No } & \multirow{2}{*}{$\begin{array}{l}\text { Age and } \\
\text { sex }\end{array}$} & \multirow{2}{*}{$\begin{array}{c}\text { Duration } \\
\text { of diabetes }\end{array}$} & \multirow{2}{*}{$\begin{array}{c}\text { Duration of } \\
\text { Insulin therapy }\end{array}$} & \multirow{2}{*}{$\begin{array}{l}\% \text { Of standard } \\
\text { weight }\end{array}$} & \multirow{2}{*}{$\operatorname{Diet}(\mathrm{MJ})$} & \multicolumn{3}{|c|}{ Insulin dose (units) } \\
\hline & & & & & & Normal & Poor control & $\%$ Reduction \\
\hline 1 & $72 \mathrm{~F}$ & 6 & $3 \mathrm{yr}$ & 86 & $8 \cdot 36$ & 20 Soluble, & 14 Soluble, & 50 \\
\hline $\begin{array}{l}2 \\
3\end{array}$ & $\begin{array}{l}76 \mathrm{~F} \\
67 \mathrm{M}\end{array}$ & $\begin{array}{r}3 \\
12\end{array}$ & $\begin{array}{l}6 \mathrm{mth} \\
9 \mathrm{yr}\end{array}$ & $\begin{array}{r}85 \\
102\end{array}$ & $\begin{array}{l}7 \cdot 52 \\
9 \cdot 20\end{array}$ & $\begin{array}{l}16 \text { Mixtard } \\
16 \text { Soluble, } \\
22 \text { PZI, } \\
12 \text { Soluble }\end{array}$ & $\begin{array}{l}5 \text { Mixtard } \\
8 \text { Soluble, } \\
12 \text { PZI, } \\
6 \text { Soluble }\end{array}$ & $\begin{array}{l}69 \\
48\end{array}$ \\
\hline 4 & $74 \mathrm{~F}$ & 1 & $8 \mathrm{mth}$ & 80 & $7 \cdot 52$ & $\begin{array}{l}24 \text { Soluble, } \\
20 \text { isophane }\end{array}$ & 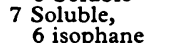 & 70 \\
\hline $\begin{array}{l}5 \\
6\end{array}$ & $\begin{array}{l}76 \mathrm{~F} \\
57 \mathrm{~F}\end{array}$ & $\begin{array}{r}4 \\
18\end{array}$ & $\begin{array}{l}4 \mathrm{yr} \\
6 \mathrm{yr}\end{array}$ & $\begin{array}{l}70 \\
91\end{array}$ & $\begin{array}{l}5 \cdot 85 \\
5 \cdot 02\end{array}$ & $\begin{array}{l}28 \text { Lente } \\
20 \text { Soluble, } \\
20 \text { isophane, } \\
20 \text { isophane }\end{array}$ & $\begin{array}{l}14 \text { Lente } \\
4 \text { Soluble, } \\
4 \text { isophane, } \\
3 \text { isophane }\end{array}$ & $\begin{array}{l}50 \\
82\end{array}$ \\
\hline 7 & $60 \mathrm{~F}$ & 3 & $3 \mathrm{yr}$ & 89 & $6 \cdot 69$ & $\begin{array}{l}6 \text { Soluble, } \\
16 \text { isophane, } \\
22 \text { isophane }\end{array}$ & $\begin{array}{l}3 \text { Soluble, } \\
11 \text { isophane, } \\
8 \text { isophane }\end{array}$ & 50 \\
\hline
\end{tabular}

Conversion: SI to traditional units-Diet: $1 \mathrm{MJ} \approx 239 \mathrm{kcal}$.

TABLE II-Patterns of change in $H b A_{1}$ concentrations related to change in diabetic control

\begin{tabular}{|c|c|c|c|c|c|c|c|}
\hline \multirow{2}{*}{ Case No } & \multicolumn{3}{|c|}{$\begin{array}{l}\text { Changes in } \mathrm{HbA}_{1} \text { (highest single value } \\
\text { during these periods expressed as a } \\
\text { percentage of the mean for weeks } \\
1-3 \text { ) }\end{array}$} & \multicolumn{2}{|c|}{$\begin{array}{l}\text { Mean 24-hour } \\
\text { Urinary glucose } \\
\text { (mmol) }\end{array}$} & \multirow{2}{*}{$\begin{array}{l}\text { Mean change in } \\
\text { fasting blood glucose } \\
(\mathrm{mmol} / \mathrm{l})^{*}\end{array}$} & \multirow{2}{*}{$\begin{array}{c}\text { Lowest plasma } \\
\text { bicarbonate } \\
(\mathrm{mmol} / \mathrm{l})\end{array}$} \\
\hline & $\begin{array}{l}\text { Weeks } \\
4-5\end{array}$ & $\begin{array}{c}\text { Weeks } \\
8-9\end{array}$ & $\begin{array}{l}\text { Weeks } \\
11-12\end{array}$ & $\begin{array}{c}\text { Weeks } \\
1-3\end{array}$ & $\begin{array}{c}\text { Weeks } \\
4-5 \\
\text { (days 3-10) }\end{array}$ & & \\
\hline $\begin{array}{l}1 \\
2 \\
3 \\
4 \\
5 \\
6 \\
7\end{array}$ & $\begin{array}{l}169 \\
174 \\
113 \\
108 \\
120 \\
115 \\
136\end{array}$ & $\begin{array}{r}117 \\
116 \\
93 \\
78 \\
112 \\
92 \\
92\end{array}$ & $\begin{array}{r}88 \\
112 \\
88 \\
81 \\
100 \\
135 \\
-\end{array}$ & $\begin{array}{r}3.4 \\
49.4 \\
16.5 \\
4.7 \\
32.5 \\
3.3 \\
85.3\end{array}$ & $\begin{array}{r}141.9 \\
204.4 \\
441.7 \\
10.5 \\
376.2 \\
85.9 \\
392.6\end{array}$ & $\begin{array}{r}4.0 \\
1.2 \\
6.8 \\
-4.4 \\
15.8 \\
3.7 \\
6.3\end{array}$ & $\begin{array}{l}26.0 \\
26.0 \\
19.0 \\
23.5 \\
25.0 \\
24.5 \\
25.5\end{array}$ \\
\hline
\end{tabular}

*Difference between mean fasting blood glucose concentration for weeks 1-3 and days 3-10 of weeks 4 and 5 . *Difference between mean fasting blood glucose concentration for weeks $1-3$ and days $3-10$ of weeks 4 and 5 .
Conversion:SI to traditional units-Blood glucose: $1 \mathrm{mmol} / 1 \approx 18 \mathrm{mg} / 100 \mathrm{ml}$. 24-hour urinary glucose: $1 \mathrm{mmol} / 24 \mathrm{~h} \approx 0 \cdot 18 \mathrm{~g} / 24 \mathrm{~h}$. Bicarbonate:
$1 \mathrm{mmol} / \mathrm{l} \approx 1 \mathrm{mEq} / \mathrm{l}$.

During the second phase of the study patients were admitted to a metabolic unit for 14 days. They continued to take their normal diet, daily 24-hour urine collections were made for measuring urinary glucose, and daily samples of blood were taken fasting and two hours after the main midday meal for estimating glucose, $\mathrm{HbA}_{1}$, electrolyte, and urea concentrations. Fasting serum lipids were measured on the first, seventh, and 14th day of this period. For the first seven days after admission patients received about half their normal daily dose of insulin (mean reduction $59 \%$; range $48-82 \%$ ). In the next seven days diabetic control was restored and the patients were then discharged home taking their usual dose of insulin.

In the next eight weeks patients followed their usual diet and insulin and undertook normal activity. They were again visited at home each week on the same morning of the week as in the initial assessment period. As before, each made a 24-hour collection of urine for measuring glucose, and fasting blood was taken for estimating glucose, lipid, and $\mathrm{HbA}_{1}$ concentrations.

\section{METHODS}

Whole blood and urinary glucose concentrations were measured by an automated glucose oxidase method. Serum cholesterol, triglyceride, and phospholipid concentrations were measured using commercial kits (Boehringer Mannheim), and lipoprotein electrophoresis was performed on cellogel.

Total glycosylated haemoglobin-that is, $\mathrm{HbA}_{1 \mathrm{a}}+\mathrm{b}+\mathrm{c}$-was estimated in each blood sample by both a colorimetric and a chromatographic method. Blood samples for measuring $\mathrm{HbA}_{1}$ were handled in exactly the same way for inpatients and outpatients. They were collected into tubes containing EDTA and remained at room temperature for up to one hour after collection. The amount of $\mathrm{HbA}_{1}$ measured by either method did not change significantly when blood samples were left standing at room temperature for up to four hours instead of being refrigerated immediately. Thereafter, the storage procedure depended on the method of analysis. Samples for chromatographic analysis were refrigerated (for up to 24 hours) until the red cells were washed and a haemolysate prepared. The haemosylate was then frozen (for no longer than seven days) until analysis. Samples for chromatographic analysis were simply refrigerated (for no longer than six days) before analysis. The amount of $\mathrm{HbA}_{1}$ was found not to change significantly in samples stored in this way.

The colorimetric method, based on that described by Fluckiger and Winterhalter, ${ }^{1}$ was calibrated against fructose standards to read $\mathrm{HbA}_{1}$ as $\mathrm{mg}$ fructose $/ \mathrm{g} \mathrm{Hb}$. In our hands this method gave a mean ( $\pm 2 \mathrm{SD}$ ) value of $1.9+0.68 \mathrm{mg}$ fructose $/ \mathrm{g} \mathrm{Hb}$ for normal subjects; the intraassay coefficient of variation was $4.1 \%$, the inter-assay coefficient of variation $7.6 \%$, and the precision $\left(\sqrt{ } \varepsilon \mathrm{d}^{2} / 2 \mathrm{n}\right.$, where $\mathrm{d}=$ the difference between duplicate assays) 0.03 . Using Biorad microcolumns the mean $\mathrm{HbA}_{1}$ ( \pm 2 SD) for normal subjects was $7 \cdot 7 \pm 1 \cdot 70 \%$ total haemoglobin, the intra-assay coefficient of variation $1.6 \%$, the inter-assay coefficient of variation $2.9 \%$, and the precision 0.26 . The correlation coefficient for the two methods in this laboratory was 0.90 .

In a group of 44 consecutive, newly diagnosed, untreated diabetics and 47 normal subjects we found a close correlation between total $\mathrm{HbA}_{1}$ and both the fasting blood glucose concentration $(\mathrm{r}=0.89)$ and the area enclosed by the blood glucose curve $(r=0.85)$ during a $50 \mathrm{~g}$ oral glucose tolerance test.

$\mathrm{HbA}_{1}$ measured daily for five days in normal subjects varied very little. The mean values $( \pm S D)$ for each subject (expressed as $\mathrm{mg}$ fructose $/ \mathrm{g} \mathrm{Hb}$ ) were: subject $1,1.80 \pm 0.07$; subject $2,1.81 \pm 0.18$; subject $3,1 \cdot 83 \pm 0 \cdot 21$; subject $4,1 \cdot 86 \pm 0 \cdot 18$; subject $5,1 \cdot 85 \pm 0 \cdot 12$.

\section{Results}

\section{HBA $_{1}$ AND 24-HOUR URINARY GLUCOSE}

Measurement of the 24-hour urinary glucose excretion was used as the main index of overall control of blood glucose, supplemented by measurement of fasting and postprandial blood glucose concentrations. These two indices of diabetic control were closely related in all patients studied. For clarity only the values for 24-hour urinary glucose and the corresponding $\mathrm{HbA}_{1}$ concentration on the morning of completing the collection are plotted for individual patients in the figure.

Four patients (cases 1,2,5, and 7) had an increase in $\mathrm{HbA}_{1}$ concentrations of $20 \%$ or more (table II) in the fourth or fifth week of the 
study. The peak occurred within 10 days of reducing the dose of insulin and coincided with the period of heaviest glycosuria. There was a secondary, much smaller, rise in $\mathrm{HbA}_{1}$ concentration of doubtful significance $(12-17 \%)$ in the eighth or ninth week of the study-about five to six weeks after the period of poor control-cases 1,2 , and 5 . Control was not optimal in case 2 in the follow-up period, but was considerably better than in the period of poor control. Unfortunately, follow-up was limited to three weeks in case 7.

In contrast, two patients (cases 3 and 6) showed no acute rise in $\mathrm{HbA}_{1}$ concentration despite heavy glycosuria when their insulin was reduced. One (case 6) showed a significant rise $\left(35^{\circ}{ }_{0}\right)$ in $\mathrm{HbA}_{1}$ concentration in the 11 th week of the study - that is, eight weeks after the period of poor control; the other patient (case 3) showed no change whatsoever in $\mathrm{HbA}_{1}$ throughout the study despite the acute metabolic decompensation for 10 days. Case 4 showed minor and insignificant fluctuations in $\mathrm{HbA}_{1}$ concentration during the fourth and fifth weeks of the study when the reduced insulin dose resulted in only a minimal increase in glycosuria. There was no secondary peak.

There was no significant difference in the pattern of change in $\mathrm{HbA}_{1}$ concentration in individual patients when it was estimated by colorimetric and chromatographic methods (see figure, cases 1 and 3).

These patterns of change in $\mathrm{HbA}_{1}$ concentrations in individual patients are summarised in table II and related to changes in diabetic control.

\section{OTHER VALUES}

Fasting blood glucose-The mean fasting and postprandial blood glucose concentrations for each patient are shown in table III.

Plasma urea and electrolytes were measured twice daily during the period of poor control to monitor the degree of metabolic decompensation. No changes sufficient to warrant terminating the study were observed (table II).

Serum lipids and lipoproteins-The fasting serum concentrations of cholesterol, triglycerides, and phospholipids showed no significant trend or pattern throughout the study.

\section{Discussion}

$\mathrm{HbA}_{1 \mathrm{c}}$ (the principal component of $\mathrm{HbA}_{1}$ ) is thought to be formed by condensation of glucose with the $N$-terminal aminogroups of the $\beta$ chain of HbA by a relatively slow, probably non-enzymatic, process continuing throughout the life span of the erythrocyte and its rate of synthesis seems to be a function of the blood glucose concentration. ${ }^{2}$

An early study ${ }^{3}$ showed that there was no correlation between concentration of $\mathrm{HbA}_{1 \mathrm{c}}$ (measured by macrocolumn
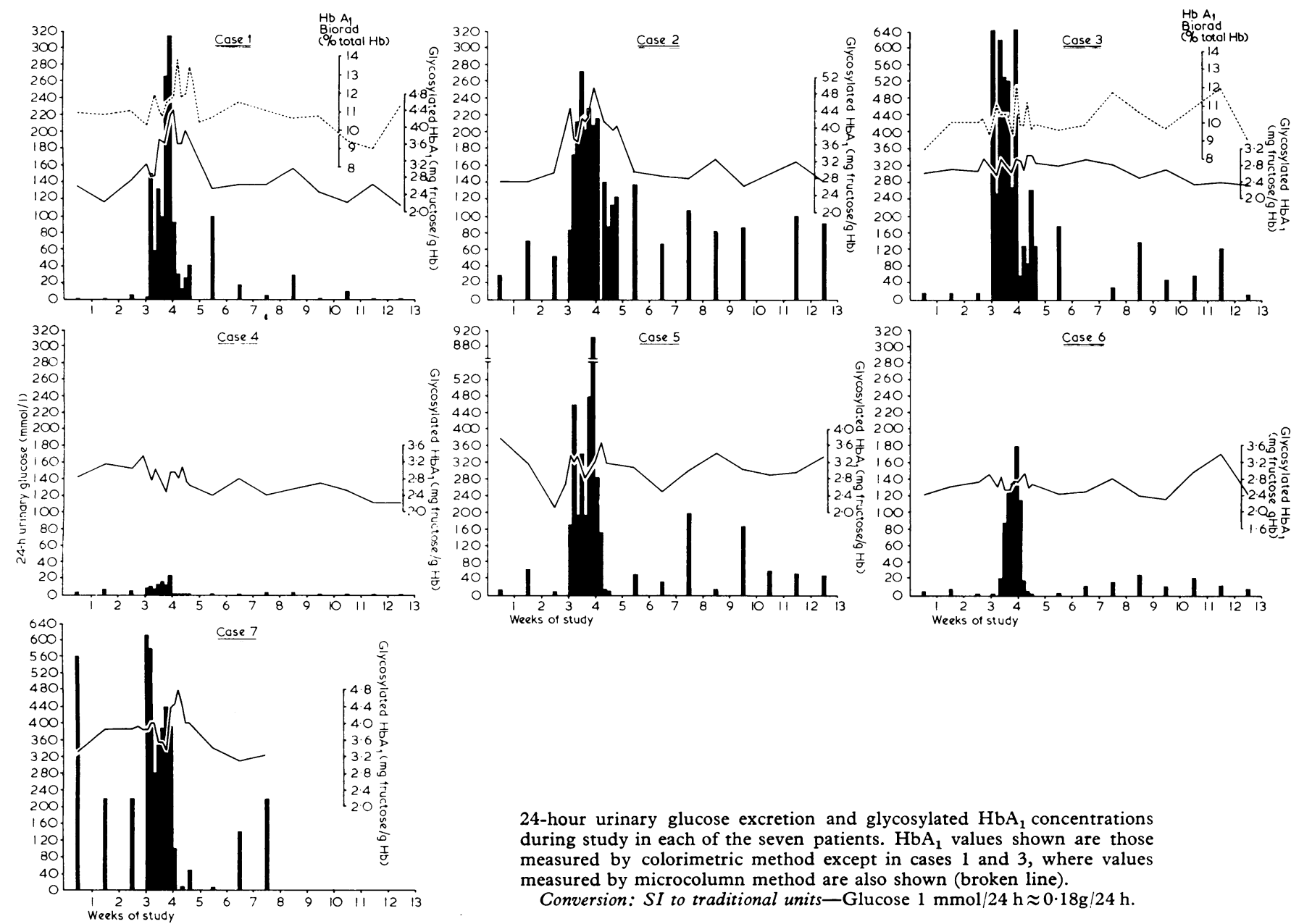

\begin{abstract}
24-hour urinary glucose excretion and glycosylated $\mathrm{HbA}_{1}$ concentrations during study in each of the seven patients. $\mathrm{HbA}_{1}$ values shown are those measured by colorimetric method except in cases 1 and 3 , where values measured by microcolumn method are also shown (broken line).
\end{abstract}

Conversion: SI to traditional units-Glucose $1 \mathrm{mmol} / 24 \mathrm{~h} \approx 0 \cdot 18 \mathrm{~g} / 24 \mathrm{~h}$.

TABLE III-Mean ( \pm SEM) fasting blood glucose concentrations (mmol/l) in initial assessment period and on days 3-10 of inpatient study and postprandial concentrations on days $3-10$ of inpatient study.

\begin{tabular}{|c|c|c|c|c|c|c|c|c|c|c|c|}
\hline Case No & & & & & 1 & 2 & 3 & 4 & 5 & 6 & 7 \\
\hline $\begin{array}{l}\text { Fasting blood glucose: } \\
\text { Assessment period } \\
\text { Inpatient gtudy (days 3-10) } \\
\text { Postprandial blood glucose ... }\end{array}$ & $\begin{array}{l}. \\
\therefore\end{array}$ & $\begin{array}{l}\cdots \\
\cdots\end{array}$ & $\begin{array}{l}\cdots \\
\ldots\end{array}$ & $\begin{array}{l}\cdots \\
\cdots\end{array}$ & $\begin{array}{l}11.5 \pm 0.69 \\
15.5 \pm 1.06 \\
10.9 \pm 0.86\end{array}$ & $\begin{array}{l}7 \cdot 1 \pm 0.40 \\
8 \cdot 3 \pm 0.41 \\
9 \cdot 7 \pm 0.80\end{array}$ & $\begin{array}{c}9 \cdot 1 \div 3 \cdot 2 \\
15 \cdot 9 \pm 1 \cdot 98 \\
17 \cdot 4 \pm 2 \cdot 12\end{array}$ & $\begin{array}{l}9 \cdot 6 \pm 1 \cdot 71 \\
5 \cdot 2 \pm 0 \cdot 23 \\
7 \cdot 6 \pm 1.09\end{array}$ & $\begin{array}{r}2 \cdot 2: 0 \cdot 23 \\
18 \cdot 0: 0.71 \\
18 \cdot 6 \pm 0.87\end{array}$ & $\begin{array}{r}7.7 \pm 1.08 \\
11.4 \pm 0.65 \\
11.8 \pm 2.06\end{array}$ & $\begin{array}{r}7.7 \pm 0.53 \\
14.0 \pm 1.67 \\
12.9 \pm 1.61\end{array}$ \\
\hline
\end{tabular}


chromatography) and the type of diabetes, duration of disease, age, or presence of complications. Other studies have variously shown good statistical correlation between the concentration of $\mathrm{HbA}_{1 \mathrm{c}}$ (measured by macrocolumn chromatography) and the fasting and peak blood glucose concentration during an oral glucose tolerance test, ${ }^{4}$ the mean blood glucose concentration immediately before and one hour after the three meals of a day, 5 and the mean of several daily plasma glucose values in diabetics being treated in various ways. ${ }^{6}$

In another study ${ }^{7}$ the relationship between the concentration of $\mathrm{HbA}_{1 \mathrm{c}}$ (measured by an electrofocusing method) and various indices of blood glucose control obtained over the previous eight weeks was examined. $\mathrm{HbA}_{1 \mathrm{c}}$ concentrations correlated with neither the mean fasting or postprandial blood glucose concentration nor the 24-hour urinary glucose but they did correlate with semiquantitative preprandial urine analysis.

The time relation between changes in $\mathrm{HbA}_{1 \mathrm{c}}$ concentration and in glucose tolerance and diabetic control has not been clearly defined. Koenig et al $l^{5}$ stated that a fall in $\mathrm{HbA}_{\mathbf{1 c}}$ concentration may lag three to four weeks behind improved diabetic control as judged by diminished urinary glucose excretion. Paulsen and Koury ${ }^{8}$ found that $\mathrm{HbA}_{1 \mathrm{c}}$ concentrations were high in patients with diabetic ketoacidosis and that after treatment the concentration fell slowly, taking at least a month to reach the level commonly found in non-ketotic diabetics. Ditzel and Kjaergaard ${ }^{9}$ studied the response of $\mathrm{HbA}_{1}$ concentrations to treatment of newly diagnosed diabetic patients and found that it took 25 to 80 days to approach normal, depending on the initial $\mathrm{HbA}_{1}$ concentration and the blood glucose control achieved. Brooks $e t a l^{10}$ found considerable variation in individual patterns of response of $\mathrm{HbA}_{1}$ concentrations to treatment of the diabetes, which could not obviously be accounted for by differences in the overall response of the blood glucose. The observations of Leslie et $a l^{11}$ indicated that "a single $\mathrm{HbA}_{1}$ estimation may relate to a shorter period of hyperglycaemia than has been suggested." Svendsen et $a l^{1213}$ have provided evidence from studies conducted both in vivo and in vitro that a significant proportion of $\mathrm{HbA}_{1}$ is formed by a fast and rapidly reversible process. This is consistent with a saturable system of glycosylation as suggested by Graf et al. ${ }^{14}$

The fact that four of our seven patients had an acute rise and fall in $\mathrm{HbA}_{1}$ concentrations during the period of poor control, which was more impressive than any later rise, supports the concept that fast and rapidly reversible glycosylation can occur in at least some insulin-dependent diabetic patients. In contrast, two other patients with very significant hyperglycaemia and glycosuria during the period of poor control showed no acute rise in $\mathrm{HbA}_{1}$ concentrations. There was no obvious difference between these two groups of patients to account for their different patterns of $\mathrm{HbA}_{1}$ response. We are confident that these varied responses are real and not simply due to methodological error, since two methods of estimation, which use different principles of measurement, showed similar patterns of $\mathrm{HbA}_{1}$ response in individual patients.

Our studies in'newly diagnosed, untreated diabetic patients (unpublished) confirm that in general the rate of synthesis of $\mathrm{HbA}_{1}$ is a function of the blood glucose concentration-that is, in groups of such patients the relationship between blood glucose and $\mathrm{HbA}_{1}$ concentrations holds. Nevertheless, the considerable individual variation, shown in the response of $\mathrm{HbA}_{1}$ to treatment of diabetes ${ }^{10}$ and here to a period of poor control, may diminish the clinical usefulness of $\mathrm{HbA}_{1}$ concentrations as a monitor of overall diabetic control in individual diabetics. This may apply particularly to the insulin-dependent diabetic, in whom rapid and short-term fluctuations in blood glucose concentration more commonly occur, and we suggest that single values for $\mathrm{HbA}_{1}$ should be interpreted with considerable caution in these patients.

More detailed studies are required in insulin-independent patients and more information is needed about the sensitivity of $\mathrm{HbA}_{1}$ concentrations in detecting periods of poor control. The fact that only one patient (case 6 ) showed a significant rise in
$\mathrm{HbA}_{1}$ concentrations in the two months of observation after the period of poor control suggests that $\mathrm{HbA}_{1}$ may be a relatively insensitive method of detecting short periods of poor diabetic control.

We thank Nicola Christie, Carol-Anne McKechnie, and Susan Taylor for skilled technical help and the volunteers for their help. We are also grateful for a grant from the clinical research fund of the Lothian Health Board in support of this work.

\section{References}

1 Fluckiger R, Winterhalter $\mathrm{KH}$. In vitro synthesis of hemoglobin $\mathrm{A}_{1 \mathrm{c}}$. FEBS Letters 1976;71:356-60.

2 Bunn FH, Haney DN, Kamin S, Gabbay KH, Gallop PM. The biosynthesis of human haemoglobin $\mathrm{A}_{1 \mathrm{c}}$. Slow glycosylation of haemoglobin in vivo. $\mathcal{F}$ Clin Invest 1976;57:1652-9.

3 Trivelli LA, Ranney HM, Lai H-T. Hemoglobin components in patients with diabetes mellitus. N Englf Med 1971;284:353-7.

4 Koenig RJ, Peterson CM, Kilo C, Cerami A, Williamson JR. Hemoglobin $\mathrm{A}_{1 \mathrm{c}}$ as an indicator of the degree of glucose intolerance in diabetes. Diabetes 1976;25:230-2.

${ }^{5}$ Koenig RN, Peterson CM, Jones RL, Saudek C, Lehrman M, Cerami A. Correlation of glucose regulation and hemoglobin $A_{1 c}$ in diabetes mellitus. N Englf Med 1976;295:417-20.

${ }^{6}$ Gonen B, Rubenstein AH, Rochman H, Tanega SP, Horwitz DL. Haemoglobin $A_{1}$ as an indicator of metabolic control of diabetic patients. Lancet 1977; ii :734-6.

${ }^{7}$ Lanoe R, Soria J, Thibult N, Soria C, Eschwegg E, Tchobroutsky E. Glycosylated haemoglobin concentrations and Clinitest results in insulin-dependent diabetes. Lancet 1977; ii:1156-7.

8 Paulsen EP, Koury M. Hemoglobin $A_{1 c}$ levels in insulin-dependent and -independent diabetes mellitus. Diabetes 1976;25:890-6.

${ }^{9}$ Ditzel J, Kjaergaard J-J. Haemoglobin $A_{1 c}$ concentrations after initial insulin treatment for newly diagnosed diabetes. $B r$ Med F 1978; :741-2.

${ }^{10}$ Brooks AP, Baird JD, Nairn IM. Rate of change of haemoglobin $A_{1}$ in diabetic patients. $\operatorname{Br} M e d f 1979 ; 2: 275$.

${ }^{11}$ Leslie RDG, Pyke D, John PN, White JM. How quickly can haemoglobin $\mathrm{A}_{1}$ increase ? $\mathrm{Br} \mathrm{Med} \mathcal{F} 1979 ; 2: 19$

12 Svendsen PA, Christiansen JS, Welinder B, Nerup J. Fast glycosylation of haemoglobin. Lancet 1979 ; :603.

13 Svendsen PA, Christiansen JS, Anderson AR, Welinder B, Nerup J. Fast glycosylation of haemoglobin. Lancet 1979;i :1142-3.

${ }^{14}$ Graf RJ, Halter JB, Porte D, Jr. Glycosylated hemoglobin in normal subjects and subjects with maturity-onset diabetes. Diabetes $1978 ; 27$ : 834-9.

(Accepted 21.7uly 1980)

ONE HUNDRED YEARS AGO We regret to learn that the Local Government Board have found it necessary to call on $\mathrm{Mr} R$ Bruce, the Medical Superintendent of the Sick Asylum, Upper Holloway, belonging to the Holborn Union, to send in his resignation; and the regret we entertain is not lessened on perusal of the letter addressed to that gentleman by the Board. It would appear that a patient, of the name of Stapleton, was admitted into the infirmary suffering from congestion of the lungs and delirium. Unfortunately he was not seen on admission by $\mathrm{Mr}$ Bruce, but only by the assistant medical officer, and in the course of that night he was put into a bath, without any order for the same by the medical officer, by two pauper attendants. Subsequently he was sent, under the direction of $\mathrm{Mr}$ Bruce, we presume on account of his mental excitement, to the Gray's Inn Road Workhouse, a distance of about four miles, where he shortly afterwards died; and on post mortem examination, it was found that the cause of death was inflammation of the lungs. There were some other charges of want of carefulness, and of refusal to admit cases to the asylum, preferred against $\mathrm{Mr}$ Bruce; and these, together with Stapleton's, above quoted, led to the Board peremptorily demanding his resignation. We would earnestly point out to gentlemen holding poor-law appointments, that they cannot be too particular in examining patients as to their fitness to bear a journey ere they direct their removal from a district to a workhouse, or from this latter to a hospital, lunatic, or sick asylum; for, if the patient should happen to die shortly after such removal, the medical officer would be apt to incur much blame. And it is not merely for their own sake, but for the credit of the profession to which they belong, that the utmost circumspection is necessary on the part of all gentlemen holding these appointments. (British Medical fournal, 1880.) 